https://cssr.uitm.edu.my/2018/

5th International Conference on Science and Social Research

Le Meridien Kota Kinabalu Hotel, 5 - 6 December 2018

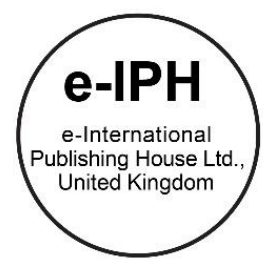

\title{
Process Creative: From four style of paintings in Sabah
}

\author{
Trihanawati Supriyono, Mohd Puad Bebit \\ Faculty of Humanities, Arts and Heritage, \\ University of Malaysia Sabah, Jalan UMS, Kota Kinabalu 88400, Sabah, Malaysia \\ trihana33332@gmail.com, sifuart@ums.edu.my \\ Tel: +60146772627
}

\begin{abstract}
The creative process usually refers to the creation of something new and unique. This paper discussed the process creation of the four genres in painting that is applied by visual artists in Sabah. Researchers used the theoretical framework approach from the updated model of process creation in the visual art-making domain to explain the operation of producing intellectual property in visual art mainstream. This research involved interview process for 20 artists from Northern Borneo, Sabah. The outcome of this research explained the differentiation between four approaches of painting genre in the form of the creative process involved.
\end{abstract}

Keywords: Process creative, the genre of painting, Sabah's painting

eISSN: 2398-4287@ 2020. The Authors. Published for AMER ABRA CE-Bsby e-International Publishing House, Ltd., UK. This is an open access article under the CC BYNC-ND license (http://creativecommons.org/licenses/by-nc-nd/4.0). Peer-review under responsibility of AMER (Association of Malaysian Environment-Behaviour Researchers), ABRA (Association of Behavioural Researchers on Asians) and cE-Bs (Centre for Environment-Behaviour Studies), Faculty of Architecture, Planning \& Surveying, Universiti Teknologi MARA, Malaysia.

DOI: https://doi.org/10.21834/ebpj.v5iSI3.2541

\subsection{Introduction}

Visual arts cover works of art from various medium and media approaches such as paintings and sculpture. Art has multiple definitions and even deep discussion which has been done by academia since decades ago. Among the well-known philosophers in discussing the theory of art are 'imitation' by Plato, 'redemption' by Nietzsche, 'the communication of feelings' by Tolstoy, 'fetish' from Adrian Piper and 'virtual' from Douglas Davis. However, the updated definition indicated that art gives its meaning based on the perspective of the audience itself (Bourdieu \& Darbel, 1997; Dawey, 1989). Besides, other statements stated the Experience of the visual arts has two components, namely cognition and emotion (Baltissen \& Ostermann, 1998; Silvia 2005). This definition also motivates researchers to select the scope of the study on the analysis of creative processes in the work of art.

According to Emre (2012), to be an original, unique and contemporary artist that is permanent, every work that has been produced should be the result of a discovery. He also explained that "although artistic results are unexpected or magical discovery as an artist, it must change the findings to a knowledge that can be shared and beneficial to society", which clearly showed the importance of critical thinking in producing a work of art. Necessary process and critical thinking in the creative process of creating artwork will reflect its value and quality. Hence this process showed the contemporary artistic nature that should be applied in each of the works. However, intellectual property should be viewed again and evaluated for its quality.

eISSN: 2398-4287C 2020. The Authors. Published for AMER ABRA cE-Bsby e-International Publishing House, Ltd., UK. This is an open access article under the CC BYNC-ND license (http://creativecommons.org/licenses/by-nc-nd/4.0/). Peer-review under responsibility of AMER (Association of Malaysian Environment-Behaviour Researchers), ABRA (Association of Behavioural Researchers on Asians) and cE-Bs (Centre for Environment-Behaviour Studies), Faculty of Architecture, Planning \& Surveying, Universiti Teknologi MARA, Malaysia.

DOI: https://doi.org/10.21834/ebpj.v5iSI3.2541 
This is one of the reasons why the director of the Sabah Art Gallery, Madam Jennifer stated that visual arts artists in the state of Sabah needed to be advanced and matured in producing paintings to uplift the local artworks*. Mature in terms of technique and the way of thinking of an artist in which that the work produced involved deep thinking and not just from the surface. She pointed out her

\subsection{Literature Review}

The creative process involved in the production of various artwork for different art genre may have differences. However, Mozart, the writers, artists and other actors generally emphasized the importance of inspiration in the creative process (Harding, 1948). Some psychology literature on the creative process, humanism, and social comparison usually mentioned the importance of inspiration during creative activity (Thrash \& Elliot, 2003). Research on the creative process in psychology domain has been done for a decade such as Dudek \& Cote (1994), Getzels \& Csikszentmihalyi (1976), and Wallas (1926). Although there are numerous studies and theories produced for this topic, most of them recognized that the creative process involves four major factors (Sawyer, 2006).

Creativity literally referred to the quintessential and uniquely of human characteristic manifested in art galleries, concert halls, and science laboratories, also existing in everyday activities (Runco 2004). This leads to the definition that the product is resulting from genuine, unique and useful of creative thinking (Mumford, 2003; Ambile \& Tighe, 1993; Gardner, 1989; Sternberg, 1985). In relation to that, it is emphasized that the creative process is practical and does not refer to the phonology or formulation of a method to be a person who possesses creativity.

\begin{tabular}{|c|c|}
\hline Stage 1 & $\begin{array}{l}\text {-Artwork conception } \\
\text { The beginning process of identifying either implicit or explicit idea or feeling from ongoing art-making } \\
\text { enterprise, the interplay of life experiences and external influences that could be a potential of artwork. }\end{array}$ \\
\hline Stage 2 & $\begin{array}{l}\text { - Idea development } \\
\text { Development of idea consists of structuring and restructuring the concept which involved unconsciously } \\
\text { derived activity and implicity based. }\end{array}$ \\
\hline Stage 3 & $\begin{array}{l}\text { - Making the artwork } \\
\text { The process from the purely conceptual entity into a conceptual and physical entity considered as an } \\
\text { appropriate material and technique used. }\end{array}$ \\
\hline Stage 4 & $\begin{array}{l}\text { - Finishing the artwork and resolution } \\
\text { Development phase while preparing the work for an exhibition and evaluation either the artwork are resolved } \\
\text { or considered abandoned artwork. }\end{array}$ \\
\hline
\end{tabular}

Fig. 1: Model of the creative process in the domain of art-making by Mace and Ward (2002).

For the purposes of this research, researchers used the creative process model from Mace \& Ward (2002), which has been designed using grounded theory analysis of creativity in the domain of art-making. The study conducted by Mace referred to the work of fine arts, in general, referring two and three-dimensional applications. Justification from this creative process model been used by researchers in this study are to obtain the information in a creative world that cannot be proved through laboratory studies. Furthermore, creativity in the visual arts domain was different from the creative process, which is practised domains such as architecture, science, Scriptwriting and music (Glaveanu, 2013). A study in the field of psychological science has made more exposure on the phenomenon for this human nature using a laboratory approach, some of them was focusing on neuroscientific research on creativity that emphasized large-scale brain differences such as hemispheric differences and creative thinking generation (Jung, 2010; Fink, 2009, Chaves-Eaklie, 2007; Greake \& Hansen, 2005; Bekhtereva, 2001; Miller, 2000 and Carlsson, 2000).

Table 1. The components of process creation in the domain of art-making by Mace and Ward (2002).

\begin{tabular}{|c|c|c|c|}
\hline Stage 1 & Stage 2 & Stage 3 & Stage 4 \\
\hline Artwork conception & Idea development & Making the artwork & $\begin{array}{l}\text { Finishing the artwork and } \\
\text { resolution }\end{array}$ \\
\hline $\begin{array}{ll}> & \text { Idea conception. } \\
> & \text { Idea selection. }\end{array}$ & $\begin{array}{ll} & \text { We are structuring an } \\
& \text { idea. } \\
>\quad \text { Enriching, expanding and } \\
\text { discovering } \\
>\quad \text { Restructuring. } \\
>\quad \text { Evaluation. } \\
>\quad \text { Shelving or abandoning } \\
\text { the work. }\end{array}$ & 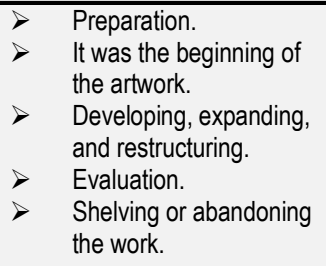 & $\begin{array}{l}>\text { She is exhibiting the artwork } \\
\text { No exhibiting the artwork. } \\
\text { Ongoing and developing art- } \\
\text { making knowledge. }\end{array}$ \\
\hline
\end{tabular}

\footnotetext{
1 Citation from Utusan Borneo 22 oct 2017
} 


\subsection{Method}

This research involved 20 listed Sabah local artists that are also the community of Sabah's visual art. The selection for the artists was based on the work that highlighted the consistency in producing works. The average respondents have experiences in the Sabah art scene for over ten years. The majority of their age ranges are the 40s. There are seven informants represent the genre of Photorealism art, 5 represent Abstract, 4 represent Contemporary painting, and 3 represent Naive art genre. In order to gather the descriptive data and visual observation, a semi-structured interview for every participated artist was conducted. An observation was constructed to accommodate unanticipated discussion from the initial data sources. After the interview took place, the recorded data are analyzed using the process of creative coding frame presented in diagram 1,2, 3 and 4

\subsection{Results and Discussion}

\subsection{Photorealism painter}

Referring to the following diagram 1, the group of painters in this stream was more likely to be involved in the activity of the fourth stage. Stage four was the exhibition stage, and the resolution has influenced the overall creative process by $39 \%$, followed by the third stage of Making artwork by $39 \%$. This clearly showed that photorealism paintings do not involve the process of developing the idea (second stage) and devising the artwork concept (first stage). The second stage of the creative process involved components such as structuring an idea, enriching, expanding, discovering idea, restructuring idea, followed by evaluation of idea and shelving or abandoning the work. This clearly showed that the works of photorealism painters had set aside the development process of ideas in their art-making process.

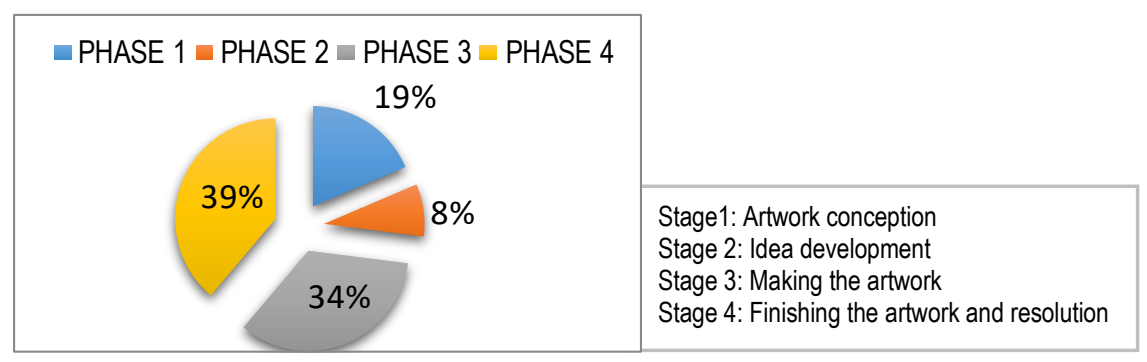

Diagram1: Result for Photorealisme painting

\subsection{Naive painter}

The naive painting also revealed the weighting on the first stage for the initial conceptual idea during their creative process. During the stage of idea conception, the abstract painter seeks to identify either implicit or explicit idea or feeling that could be the potential as the idea of their artwork. Then, the preliminary idea will go through the idea selection process before each idea was developed conceptually and physically. As mentioned in diagram 2, the Naive paintings in Sabah focused more on the selection of subjects or images that represented the idea of conveying their work of art. One of the explanations for this was in the brainchild of naive art gives an important role in explaining the whole production work (Walker,1992). The naive painting was less involved in developing ideas in their creative process because the growth of idea was based. On a subject selection. The current study for the idea selection process was sufficient to support the overall development of conceptual, physical and expression in their personal artworks.

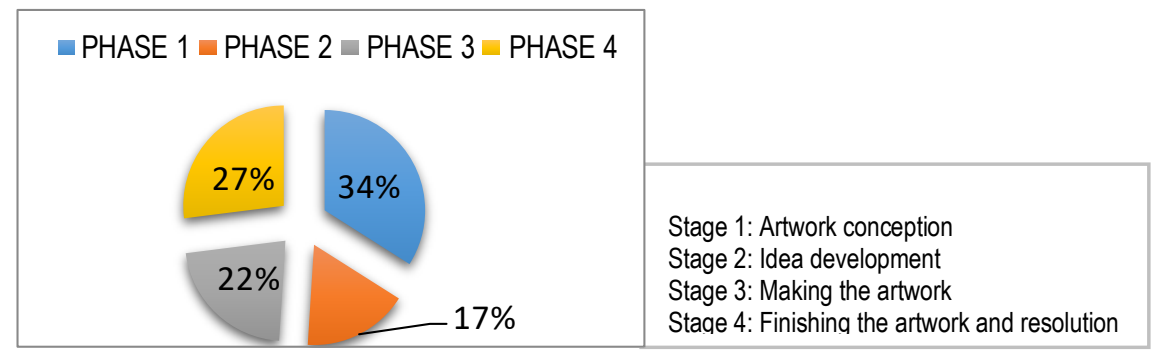

Diagram 2: Result for Naive painting

\subsection{Abstract painter}

Referring to the following diagram 3, the work of abstract artists showed the percentage of activity in the first stage was higher than the percentage of the other three phases. The first stage of designing the work conception included the components of initial inspiration and idea selection. The entire creative process was almost balanced but clearly showed the flaw in the second stage, which are developing the idea. The painters are more focused on the preliminary ideas, and less emphasized on the importance of the 
idea developed in the production of work and the time of its application on the canvas surface. This was influenced by the institutive emotion and personal spontaneity of the painter himself.

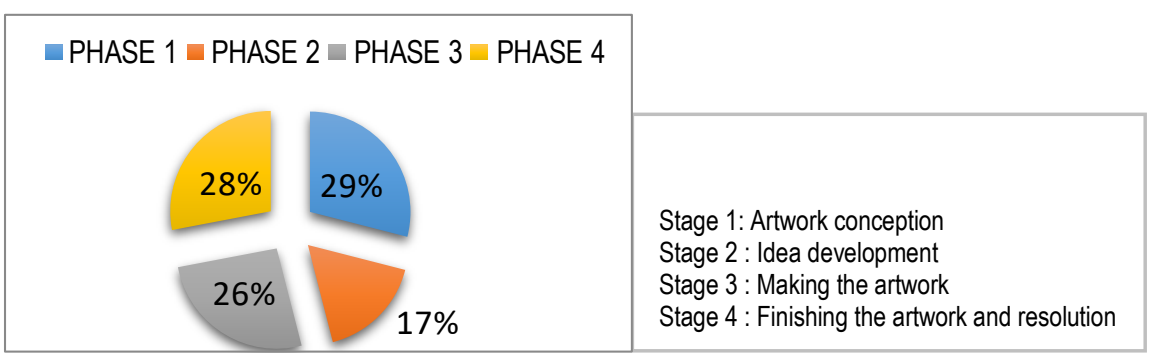

Diagram 3: Result for Abstract painting

\subsection{Contemporary painter}

The results of a contemporary artist base on diagram 4, analysis can be seen that the creative process involved was uniform and balanced in the four phases involved. Each phase recorded has over $20 \%$ activity involving the art-making process. This showed that the painter managed a delicate balance between the art-making activity and creative discovery outcomes. However, diagram 4 displayed that the action in the third stage was more progressive and effective in term of advancing process of development. Most of the contemporary painting was engaged in a various and dynamic combination materials or techniques to challenge the boundaries that were already well underway in the painting realm. That was one of the reasons contemporary painting comprised a few different experiments to convey their personal expressions in the artwork and selection of materials or techniques accordingly. The technical action to construct the body of artwork was conducted during the third stage and it was composed during the development, expanding and restructuring point

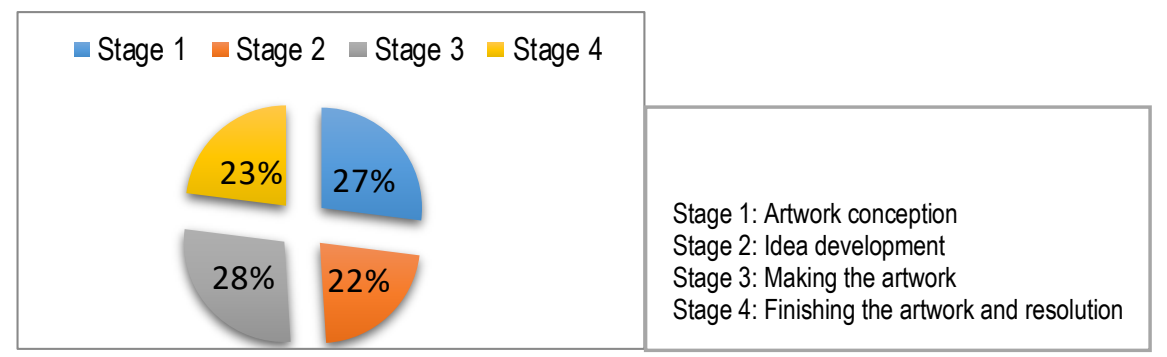

Diagram 4: Result for Contemporary painting

\subsection{Conclusion}

This study clearly showed that the photorealism paintings have a less balanced process of creativity compared to the other three realms of paintings appraised by the painters in Sabah. Most of the photorealism painting in Sabah was considered as a craft and are intended for commercial purposes. Hence, the creative processes involved are minimal to facilitate quick and easy creation of work to increase productivity without emphasizing the quality of the results in terms of intellectual and critical thinking. This was also due to the clients such as tourists, or craft enthusiasts are often the target for the painters. The clients were less concerned about the quality of the work from the aspect of intuition and the value of the art essence. Reflecting on the issue of visual art scenarios in Sabah, this study has proved that the paintings from Photorealism domain showed a lack in the aspect of creative and analytical thinking creative process. It was seen from the action results that occurred in the idea development process prior to the application of ideas on canvas. The contemporary realm manages to persuade a lot of active development in the second and third stage of the creative process. Development process constituted experiences of an artist, find the base in which that has been previously done, that is the excitation of some contact with the world undergoes a successive transformation (Dewey,1934). This activity explained the impulse, and it's direct towards fulfilment between the artist and his personal intuition (Glaveanu, 2012). Literally, the distinction between modern and contemporary art is modern art challenges the conventions of representation, while contemporary art challenges the very notion of an artwork (Heinich, 2014). The character of contemporary itself is demanding a critical action in producing a substantial work of art in terms of physical and conceptual values.

The whole creative process involved in the four stages explained the differences regarding their distinct approaches highlighted in each of these stages. An abstract painting is an attempt to reproduce an illusion of visible reality. Most of the abstract painters referred to abstract expressionism using a spontaneous and subconscious creation approaches to create a new kind of art which would encompass the fundamental changes taking place in technology, science, and philosophy. The spontaneous institution happened during the phase of making an artwork consists of developing, expanding and restructuring visually and conceptually in regard to the personal expression content. Both abstract and naive painting give more attention to getting inspiration or motivation for the next move 
due to the highest-ranking recorded in the first phase. An inspiration can encourage a creative idea to fruition, and that creative inspiration often takes a specific form of transmission called actualization (Thrash, 2010).

According to Duxbury. L (2007), David Thomas quoted that every practice of creating works of art are unique. Which mean artistic practice was complexly informed of physical, theoretical and intellectual activity where public and privet world meet. A word by the public and private world referred to the different intertwined objective, subjective, rational and intuitive processes owned by each artist. Each form was practised by each artist differs according to his own background, Experience, knowledge or objective. This study has successfully demonstrated that subjective process explanation based on the fundamentals and ethics realm from their art styles that they pursue. In summary, the present study aimed to analyze the creative process implicate during the painting artmaking by selecting four painting styles in Sabah using the same coding frame. Analysis results showed the possible similarity and differences in the process of creative patterns between that realms in order to understand the current Sabah's art scene. This finding also is very fruilful for our efforts to build awareness for the visual art community in Sabah in terms of enhancing creativity and expression setting and beyond.

\section{Acknowledgements}

This research was financed by UMSGreat research centre and innovation from Universiti Malaysia Sabah (UMS)

\section{References}

Amabile. T.M, Tighe. E. 1993. Questions of creativity: Brockman, J. (Ed.), Creativity. Simon \& Schuster, New York (NY), pp. 7-27.

Chavez-Eakle. R.A, Graff-Guerrero. A Garcia-Reyna. J.C, Vaugier. V, Cruz-Fuentes. C. 2007. Cerebral blood flow associated with creative performance, a comparative St.

Dewey, J. (1989). Having an experience. In J. A. Boydston (Ed.), John Dewey: The later works. Carbondale, IL: Southern Illinois University Press.

Dudek. S. Z. \& Cote. R. 1994. Problem finding revisited, problem-solving, and creativity: M. A. Runco (Ed.).(pp. 130-150). Norwood, NJ: Ablex.

Duxburt.L, Gtierson.E.L, \& Waite.D (2007) Thinking through practice: Art as research in the Academy. International Journal of Creative Media. p. 140-146.

Emre.T (2012) Painting education and artistic evolution, Elsevier Ltd Publisher, DOI: 10.1016/j.sbspro.2012.06.283

Fink. A, Grabner. R.H, Benedek. M, Reishofer. G, Hauswirth. V, Fally, M, Neuper. C, Ebner. F, Neubauer. A.C. 2009. The creative brain, investigation of brain activity during creative problem solving by means of eeg and fmri: Human Brain Mapp. 30, 734-748

Gardner. H. 1989. To Open Minds: Basic. New York (NY) 6

Getzels. J. W, Csikszentmihalyi. M. 1976. The Creative Vision: A Longitudinal Study of Problem Finding in Art: John Wiley and Sons, New York.

GlaveanuV, P (2012) Creativity and folk art: a study of creative action in tradition craft. Psychol. Aesthet. Creat, Art Online First.

GlaveanuV, P (2013) Creativity as action: findings from five creative domains, fortiers in psychology DOI: 10.3389/fpsyg.2013.00176

Gortais B, 2003 Philosophical Transactions: Biological Sciences, Vol. 358, No. 1435, The AbstractionPaths: From Experience to Concept (Jul. 29,2003$)$, pp. 12411249: The Royal Society.

Harding,R.E.M.(1948). AnAnatomyofInspiration:AndAnEssayontheCreative Mood. Cambridge:W.HefferandSons

Heinich, N. (2014). Le paradigme de l'art contemporain. Structures d'une révolution artistique. Gallimard.

Martabatkan Seni Tempatan. (n.d.). Retrieved October 22, 2017, from https://www.pressreader.com/malaysia/utusan-borneo-sabah/20171022/282127816717757.

Melissa.E \& Charles.D (2011) evaluation and generative modes of thought during the creative process, Neurolmage Hournal, DOI :10.1016/j.neuroimage.2011.08.008

Mumford, M.D., Baughman, W.A., \& Sager, C.E. 2003. Picking the right material: Cognitive processing skills and their role in creative thought: In M.A. Runco (Ed.), Critical creative processes (pp. 19-68). Cresskill, NJ: Hampton Press.

Runco, M.A., 2004. Creativity. Annu. Rev. Psychol. 55, 657-687.

Sawyer,R.K.(2006). ExplainingCreativity:TheScienceofHumanInnovation. New York,NY:Oxford.

Silvia, P. J. (2005b). Cognitive appraisals and interest in visual art: Exploring an Appraisal Theory of Aesthetic Emotions. Empirical Studies of the Arts, 23, 119-133.

Sternberg. R.J., 1985. Implicit theories of intelligence, creativity, and wisdom: J. Pers. Soc. Psychol. 49, 607-627

Thrash,T.M.,andElliot,A.J.(2003).Inspirationasapsychologicalconstruct. J. Pers.Soc.Psychol. 84, 871-889.

doi:10.1037/0022-3514.84.4.871 
Thrash,T.M.,Elliot,A.J.,Maruskin,L.A.,andCassidy,S.E.(2010a).Inspiration and the promotion of well-being :test so causality and mediation. J. Pers.Soc. Psychol. 98, 488-506.doi:10.1037/a0017906.

Utusan Borneo 22 oct 2017 https://www.pressreader.com/malaysia/utusan-borneo-sabah/20171022/282127816717757

Wallas. G. 1926. The art of thought: Harcourt-Brace. New York 